\title{
RELATIVITY IN BUSINESS MORALS
}





\title{
RELATIVITY IN BUSINESS MORALS
}

\author{
BY \\ HENRY M. ROBINSON
}

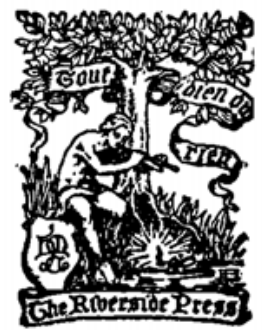

BOSTON AND NEW YORK

HOUGHTON MIFFLIN COMPANY

Che Ribersitue Fress Cambrituge

1928 
COPYRIGET, 1928, BY THE REGENTS OF THE UNIVERSITY OF CALIFORNIA

ALL RIGHTS RESERVED

Che Ribersibe Press

CAMBRIDGE - MASSACHUSETTS

PRINTED IN THE U.S.A. 


\section{BARBARA WEINSTOCK LECTURES ON THE MORALS OF TRADE}

This series will contain essays by representative scholars and men of affairs dealing with the various phases of the moral law in its bearing on business life under the new economic order, first delivered at the University ofCalifornia on the Weinstock Foundation. 
